\title{
Baker v. Carr: New Light on the Constitutional Guarantee of Republican Government ${ }^{\dagger}$
}

\section{Arthur Earl Bonfield*}

THE RECENT CASE of Baker v. Carr ${ }^{1}$ may well be notable for a variety 1 of reasons; certainly for its holding that the validity of Tennesee's legislative apportionment was justiciable when raised under the equal protection clause of the fourteenth amendment. ${ }^{2}$ But the decision may also have lasting importance for the light it casts on the guarantee clause of article IV, section 4, of the Constitution. That provision declares that the "United States shall guarantee to every State in this Union a Republican Form of Government ...." Although the particular issue involved in Baker v. Carr was disposed of solely by reference to allegations under the fourteenth amendment, ${ }^{3}$ the Supreme Court was afforded an excellent opportunity to comment on the present status of the republican form of government clause. That several of the justices actually felt impelled to do so, and at some length, may give cause for reflection about a constitutional provision long deemed beyond judicial purview.

The objectives of this brief Article are limited. First, an attempt will be made to analyze Baker v. Carr as it sheds light on the justiciability of questions raised under the guarantee. The Court's discussion of this question, though extensive, fails to clarify the present state of the law. Second, an effort will be made to demonstrate that, despite the absence of a claim based upon the guarantee clause in Baker, the case is almost certain to encourage a related kind of apportionment suit whose resolution will inevitably require the judiciary to grapple with that provision. Finally, it will be concluded that the Court can successfully entertain this future class of apportionment suits on the merits. In such cases it will face no greater difficulties or more delicate matters than it did in Baker. More specifically, it will be able to construct satisfactory standards for applying the guarantee to these new situations. But in doing so, it should make clear that its decision is grounded on the guarantee. Otherwise, its action will only further obscure the real issue and render its proper analysis and solution more difficult.

† On the history and present potential of the long dormant guarantee, see Bonfield, The Guarantee Clause of Article IV, Section 4: A Study in Constitutional Desuetude, 46 MINN. L. REv. 513 (1962).

* Assistant Professor of Law, State University of Iowa College of Law.

182 Sup. Ct. 691 (1962).

2 Id. at 720, 725, 728, 737.

$8 \mathrm{Id}$. at $698 \mathrm{n} .15,706$. 
Baker v. Carr AND THE JUSTICIABILITX OF ISSUES UNDER THE GUARANTEE

The accepted doctrine is said to be that any issue raised under the guarantee of republican government is per se not "meet for judicial determination." The untenable nature of this conclusion has been discussed elsewhere, ${ }^{5}$ but it will be reargued here in the context of the new light shed on the subject by Baker v. Carr.

In writing the opinion of the Court, ${ }^{6}$ Justice Brennan notes that certain kinds of issues will often be nonjusticiable. This is because the nature of the issue, the circumstances under which it arises, or the provision involved in its resolution may cause it to suffer from one of the following infirmities:

[A] textually demonstrable constitutional commitment of the issue to a coordinate political department; ... a lack of judicially discoverable and manageable standards for resolving it; ... the impossibility of deciding without an initial policy determination of a kind clearly for nonjudicial discretion; ... the impossibility of a court's undertaking independent resolution without expressing lack of the respect due coordinate branches of the government; ... an unusual need for unquestioning adherence to a political decision already made; or the potentiality of embarrassment from multifarious pronouncements by various departments on one question. ${ }^{7}$

An issue presents a "political question" beyond judicial competence solely if it suffers from one of these disabilities. ${ }^{8}$

Only two of the indices of nonjusticiability advanced by Justice Brennan may consign an otherwise justiciable issue to the realm of nonjusticiability because of the provision under which it is sought to be resolved. If a particular constitutional provision "textually" commits its enforcement to a "coordinate political department," or if it fails to provide "judicially discoverable and manageable standards" for the resolution of issues raised thereunder, it must be deemed beyond judicial purview. Thus, all issues sought to be resolved by reference to the guarantee clause would be nonjusticiable solely if that provision suffers from one of these disabilities. This is so, since all the other indices of nonjusticiability mentioned by the Justice inhere in the nature of the issue presented, or the circumstances under which it arises, and not in the provision that may be involved in its resolution.

4 See Bonfield, The Guarantee Clause of Article IV, Section 4: A Study in Constitutional Desuetude, 46 MINN. L. Rev. 513, 551-57 (1962).

5 Id. at 560-65.

${ }^{6}$ Justice Brennan was joined by Chief Justice Warren and Justice Black; Justices Douglas, Clark, and Stewart wrote separate concurring opinions; Justices Frankfurter and Harlan dissented, each joining in the other's opinion; Justice Whittaker did not participate in the decision.

7 Baker v. Carr, 82 Sup. Ct. 691,710 (1962).

8 Ibid. 
Justice Brennan interjects the guarantee clause into Baker v. Carr by noting that the issue presented cannot be definitively resolved until the relevance of the doctrine spawned under that provision is examined. If the case at bar shares the characteristics of the decisions rendered under the guarantee, it may be nonjusticiable despite allegations invoking the fourteenth amendment. ${ }^{9}$ It should be stressed that his ensuing discussion of the first clause of article IV, section 4, is dicta, since the claim pleaded in Baker rested solely upon the equal protection clause. ${ }^{\mathbf{1 0}}$

Justice Brennan seemingly attempts to demonstrate that any issue, insofar as it is raised under the guarantee, is automatically rendered nonjusticiable. ${ }^{11}$ However, when exactly the same issue is assailed under the fourteenth amendment, it may be fit for judicial determination. ${ }^{12} \mathrm{He}$ seems to ground this conclusion on the supposed existence of the two disabling factors just noted: the lack of standards furnished by the guarantee, and the delegation of its enforcement exclusively to Congress.

The Justice proceeds to demonstrate the paucity of "judicially discoverable and manageable standards" furnished by the guarantee by resurrecting the early case of Luther v. Borden.$^{13}$ It held that the determination of which of two competing state governments was legitimate presented a political question..$^{14}$ Justice Brennan notes that the factors rendering that issue nonjusticiable were "the conimitment to the other branches of the decision as to which is the lawful state government; the unambiguous action by the President [in that case], in recognizing the charter government as the lawful authority; [and] the need for finality in the executive's decision . . ." 15 Not being content with justifying Luther solely on these grounds, he suggests a further factor rendering the issue presented there "political": "the lack of criteria by which a court could determine which form of government was republican." ${ }^{16}$ But this last disability, even if its existence is assumed, was irrelevant to the decision in Luther v. Borden. The issue properly before the Court in that case was disposed of before the necessity for any such determination arose. The Court declined to illegitimize one of the two competing state governments on the grounds that the

${ }^{8}$ Ibid.

10 Id. at $698 \mathrm{n.15:}$ "It is clear that appellants' federal constitutional claims rest exclusively on alleged violation of the Fourteenth Amendment."

11 Id. at 710-16.

$121 d$. at $715-17$.

1348 U.S. (7 How.) 1 (1849); see 82 Sup. Ct. at 710-14.

14 See Bonfield, supra note 4, at 533-36.

1582 Sup. Ct. at 712 . To these factors might be added the severe consequences that might flow from a decision on the merits contrary to that of the President. See Bonfield, supra note 4, at 533-36.

1082 Sup. Ct. at 712. 
Constitution and Congress had delegated that determination to the President. And he, having made that decision, had properly bound the Court.7

So Justice Brennan's conclusion that the importance of Luther v. Borden lay in its "holding that the Guaranty Clause is not a repository of judicially manageable standards which a court could utilize independently in order to identify a State's lawful government" 18 cannot be deemed controlling. The Court had already found sufficient practical reasons to bar it from any determination as there requested. And as the Justice himself notes, "the judiciary might be able to decide the limits of the meaning of 'republican form,' and thus the factor of lack of criteria might fall away." 10 He therefore admits, notwithstanding his prior citation of Luther to the contrary, that no paucity of criteria will necessarily bar the Court from enforcing the guarantee. This conclusion is reinforced by his quotation of those indices that earlier Courts have deemed requisites of republican government. $^{20}$

Justice Brennan intimates a second disability of the guarantee that would render all issues raised thereunder nonjusticiable. By quoting Luther, as well as citing the many cases in which the Court has deemed issues arising under that provision "political," he seeks to demonstrate that its enforcement was vested solely in Congress. ${ }^{21}$ But he fails to mention the admittedly few cases in which the Court has passed on the merits of claims asserted under that clause without even questioning their justiciability. ${ }^{22}$

Nor does the Justice note that the unique determination required in Luther was exclusively delegated to the President. The latter clauses of article IV, section 4, and a statute enacted in $1795^{23}$ conferred on the President the exclusive power to decide which of two competing state governments was legitimate and lawful. He was to curb insurrection by calling forth the militia on application of the proper governmental authority of a state. As a result, the obligation had been impliedly placed on him to "determine what body of men constitute the legislature, and who is the governor, before he can act." 24 While the President never actually summoned the militia, he did recognize the old governor as the executive power of

${ }^{17}$ Luther v. Borden, 48 U.S. (7 How.) 1, 42-44 (1349); see 82 Sup. Ct. at 712 ; Bonfield, supra note 4, at 534 .

1882 Sup. Ct. at 713.

19 Id. at 712 n.48.

20 Ibid.

2182 Sup. Ct. at 713-14.

22 Minor v. Happersett, 88 U.S. (21 Wall.) 162 (1875); In re Duncan, 139 U.S. 449 (1891); see Bonfield, supra note 4 , at 548-51.

231 Stat. 424 (1795), 50 U.S.C. $\$ 201$ (1958); see Luther v. Borden, 48 U.S. (7 How.) 1, 43 (1849).

24 Id. at 44 . 
Rhode Island. Further, he took measures to send the militia to his aid if it should be found necessary. "[N]o court of the United States, with a knowledge of this decision [by the President to recognize the old governor], would have been justified in recognizing the opposing party as the lawful government ...."25

Therefore, despite dicta to the contrary, ${ }^{26}$ Luther does not hold that the guarantee is solely enforceable by Congress. Rather, its holding is only that the particular determination there involved resided with the President. But in line with the dicta in Luther and the holdings of later cases relying thereon, ${ }^{27}$ Justice Brennan seems convinced that the guarantee's enforcement is exclusively committed to Congress. He does admit, however, that each case "would have to be considered in the particular fact setting presented." The Justice seems so confident of his first conclusion that he makes the rather extraordinary statement that even past the judicial inability to enforce the clause, "challenges to congressional action on the ground of inconsistency with [the guarantee] ... present no justiciable question." 28

The cases he cites to support this last proposition are wholly inapposite, for they were grounded in the unique circumstances of the Reconstruction of the South in the aftermath of the Civil War. ${ }^{30}$ Only in a footnote is it admitted that the "implication of the Guaranty Clause in a case concerning congressional action does not always preclude judicial action." ${ }^{11}$ Certainly his textual references could not have meant to convey the impression that all congressional action allegedly pursuant to the guarantee was unreviewable. Such a doctrine would be disastrous, since it would leave in Congress an unfettered and unchecked power capable of destroying all republican government..$^{32}$ And his initial assumption that the clause is enforceable in the first instance solely by Congress is as questionable as his further

25 Ibid.; see Bonfield, supra note 4, at 534.

20 Luther v. Borden, supra note 23 , at 42.

27 See, e.g., Highland Farms Dairy v. Agnew, 300 U.S. 608 (1937); Mountain Timber Co. v. Washington, 243 U.S. 219 (1917); Pacific States Tel. \& Tel. Co. v. Oregon, 223 U.S. 118 (1912). See also 82 Sup. Ct. at 713-14; Bonfield, supra note 4, at 556-57.

2882 Sup. Ct. at 712 n.48.

29 Id. at 714.

30 Id. at 714, citing Georgia v. Stanton, 73 U.S. (6 Wall.) 50 (1867) ; Mississippi v. Johnson, 71 U.S. (4 Wall.) 475 (1867); Mississippi v. Stanton, 154 U.S. 554 (1867); see Bonfield; supra note 4 , at $543-44$ n.137, 564 n.211. Justice Brennan cites two other cases that also do not support his statement. As he admits, one attacked Congress' failure to act under the guarantee, Ohio ex rel. Davis v. Hildebrant, 241 U.S. 565 (1916); the other concerned congressional action dealing with territories, to which the guarantee cannot even colorably be deened to apply, Downes v. Bidwell, 182 U.S. 244, 278-79 (1901) (dictum).

3182 Sup. Ct. at $714 \mathrm{n} .53$; see Bonfield, supra note 4, at 564-65.

32 Bonfield, sutpra note 4, at 564-65. To free any action from judicial scrutiny, all Congress need do is assert that it was acting pursuant to the guarantee. 
assumption that the Court is impotent to review Congressional action thereunder.

This conclusion becomes obvious when it is realized that no "textually demonstrable constitutional commitment of the issue to a coordinate political department" exists here. As Justice Douglas maintains in his concurring opinion,

The statements in Luther v. Borden . . . that this guaranty is enforceable only by Congress or the Chief Executive is not maintainable. Of course the Chief Executive, not the Court, determines how a State will be protected against invasion. Of course each House of Congress, not the Court, is the "judge of the elections, returns, and qualifications of its own members,"... But the abdication of all judicial functions respecting [any issue arising under the guarantee]. . . . is indefensible. ${ }^{33}$

Justice Frankfurter in his dissent lends credence to this view by his notation that article IV, section 4, "is not committed by express constitutional terms to Congress. It is the nature of the controversies arising under it, nothing else, which has nade it judicially unenforceable." 34

Can it therefore be assumed that when the nature of the issue or controversy raised under the guarantee clause does not possess any of the hallmarks of nonjusticiability, it will be examined on the merits? Logically, this must be answered in the affirmative. It makes little sense to classify all issues raised under this constitutional provision nonjusticiable regardless of their nature. The clause is neither textually committed to the exclusive enforcement of another department, nor bare of judicially discoverable or manageable standards for resolving questions dependent for their resolution upon it. ${ }^{35}$ It is therefore the "political question" aspects of the issue raised under the guarantee and not the mere invocation of that provision that should determine justiciability.

Justice Brennan abandons this seemingly satisfactory formulation, which logically would have permitted judicial enforcement of the guarantee in all cases save those in which the issue raised was nonjusticiable. $\mathrm{He}$ notes that,

This case does, in one sense, involve the allocation of political power within a State, and the appellants might conceivably have added a claim under the Guaranty Clause. Of course, as we have seen, any reliance on that clause would be futile. But because any reliance on the Guaranty Clause could not

3382 Sup. Ct. at 723 n.2.

34 Id. at 754. (Emphasis added.) But compare Justice Frankfurter's other remarks, id. at 749-54. See also Colegrove v. Green, 328 U.S. 549, 556 (1946).

35 See Bonfield, supra note 4, at 558-60, for an attempt to evolve a comprehensive mode whereby the standards provided in this clause can be satisfactorily ascertained. See also \& IV of this article infra, for some specific criteria that the guarantee might require in the area of apportionment. 
have succeeded it does not follow that appellants may not be heard on the equal protection claim which in fact they tender. True, it must be clear that the Fourteenth Amendment claim is not so enmeshed with those political question elements which render Guaranty Clause claims nonjusticiable as actually to present a political question itself. But we have found that not to be the case here. ${ }^{36}$

Thus, the same issue may be justiciable if raised under the equal protection clause, and nonjusticiable if raised under the guarantee. This seems a rather peculiar doctrine, since it is difficult to understand how an issue contains any more of the elements of nonjusticiability when pleaded under the latter provision.

The Justice attempts to bolster his conclusion by invoking Pacific States Tel. \& Tel. v. Oregon. ${ }^{37}$ It held nonjusticiable, as against claims under the due process, equal protection, and guarantee clauses, the question whether defendant could resist the enforcement of an otherwise valid statute because of its alleged invalid enactment. ${ }^{38}$ He notes that,

The due process and equal protection claims were held nonjusticiable in Pacific States not because they happened to be joined with a Guaranty Clause claim, or because they sought to place before the Court a subject matter which miglit conceivably have been dealt with through the Guaranty Clause, but because the Court beheved that they were invoked merely in verbal aid of the resolution of issues which, in its vierw, entailed political questions. ${ }^{39}$

But this statement only reaffirms that it is not the invocation of the guarantee clause that renders a case nonjusticiable, but the "political" nature of the issues presented.

However, Justice Brennan then notes approvingly several cases in which on a single issue the Court declined to hear allegations of invalidity under the guarantee, but entertained claims under the fourteenth amendment on the merits. ${ }^{40}$ From this he concludes that "the nonjusticiability of claims resting on the Guaranty Clause which arises from their embodiment of questions that were thought 'political,' can have no bearing upon the justiciability of the equal protection claim presented in this case." But he emphasizes that "it is the involvement in Guaranty Clause claims of the elements thought to define 'political question,' and no other feature, which could render them nonjusticiable. Specifically, ... such claims are not held nonjusticiable because they touch matters of state governmental organiza-

3682 Sup. Ct. at 715.

37223 U.S. 118 (1912).

38 See Bonfield, supra note 4, at 553-56.

3082 Sup. Ct. at 716. (Emphasis added.)

40 Id. at 716, citing Mountain Timber Co. v. Washington, 243 U.S. 219 (1917); ONeil v. Leamer, 239 U.S. 244 (1915). 
tion." 41 He seems here to be reverting to the sensible doctrine that it is some of the aspects of the particular issue raised, not the mere fact that the allegation is framed with reference to the guarantee, that makes it "political." Nevertheless, the net conclusion of his opinion seems to be that the issue presented in Baker v. Carr is justiciable when presented under the equal protection clause, but nonjusticiable when raised under the guarantee.

This seems rather incongruous. Neither as a textual or policy matter is the enforcement of the guarantee delegated solely to Congress; nor are there greater difficulties under this provision in defining the criteria necessary for judicial enforcement than there are under the fourteenth amendment. As a result, an issue raised under the guarantee should be deemed "political" solely if it is burdened with some of the other elements Justice Brennan notes. An issue cognizable under the fourteenth amendment, as that in Baker v. Carr, must therefore, as a logical proposition, be so under the guarantee. Since the justiciability of guarantee claims should depend solely on the nature of the issue involved, or the circumstances under whicli they arise, a case like Pacific States can be approved. There, severe consequences might have resulted from any adjudication on the merits. ${ }^{42}$ But those cases that lield the same issue justiciable under the fourteenth amendment and nonjusticiable under the guarantee must be vigorously assailed.

Baker v. Carr further beclouds the issue of the guarantee's justiciability. Justice Brennan's statement that "any reliance on ... [the guarantee] clause would be futile" in this case ${ }^{43}$ seems to approve the doctrine that any invocation of the guarantee is per se nonjusticiable. The ambiguity of some of his remarks in wlicli he talks about the "political" aspects of the issue raised as liallmarks of nonjusticiability, and the insistence by Justice Douglas that the provision is sometimes enforceable by the courts, does little to settle the point. And although Justice Frankfurter's dissent is directed at establishing that the instant case involves just those elements that have made the guarantee clause cases nonjusticiable, some of his language also reinforces the notion that it is the nature of the issue presented and not the mere reliance on the guarantee clause that may render a question "political."

\section{II}

Baker v. Carr: A GUARANTEE CASE IN DISGUISE?

Justice Frankfurter strongly disapproves of the result in Baker and maintains that its liolding represents a sub silentio decision to review on

41 Id. at 716. (Emphasis added.)

42 See Bonfield, supra note 4, at 553-56. All or a substantial portion of the state's statutes might have been voided by the kind of relief requested in that case.

4382 Sup. Ct. at 715. 
the merits issues raised under the guarantee. He insists that "to divorce 'equal protection' from 'Republican Form' [in this case] is to talk about half a question," 44 since "it is, in effect, a Guarantee Clause claim masquerading under a different label." ${ }^{45}$ But this conclusion is arguable, for it rests upon the highly doubtful assumption that the issue before the Court in Baker could not be entirely resolved by reference to established doctrines under the fourteenth amendment.

According to Justice Clark, the problem in Baker v. Carr was not in Tennessee's Constitution, for admittedly its policy has not been followed. The discrimination lies in the action of Tennessee's Assembly in allocating legislative seats to counties or districts created by it. Try as one may, Tennessee's apportionment just cannot be made to fit the pattern cut by its Constitution. ${ }^{46}$

In other words, the precise issue presented in the case was whether the legislature's refusal to apportion according to the mandate of the state's fundamental law denied injured parties any federal rights.

A state's disregard of its own constitution in order to purposefully discriminate between persons or classes of persons violates the equal protection clause of the fourteenth amendment. To support such a claim, it must be shown that the failure to observe state law is related to a purposeful design to favor one individual or class over another. Where discrimination is sufficiently shown, the right to relief under the equal protection clause is not diminished because it relates to political riglits. ${ }^{47}$

It is therefore reasonable to assume that a state legislature's purposeful disregard ${ }^{48}$ of the representational scheme mandated by its constitution, in order to keep certain classes of people from exercising their "proper weight" in that state's governing process, can be redressed solely by reference to the fourteenth amendinent. To render a decision on the merits of such a case, the republican nature of the de facto illegitimate apportionment need not even be examined. This, since the claim for redress arises solely from the state's purposefully discriminatory refusal to obey the mandates of its own law.

As a result, it can be maintained with some conviction that Justice Frankfurter erred in the particular situation raised in Baker v. Carr. The

$44 I d$. at 756.

$45 \mathrm{Id}$. at 754 .

46 Id. at 729 .

47 See generally Snowden v. Hughes, 321 U.S. I, 8-11 (1944).

48 Its failure to act when it is under a duty to do so may certainly be deemed "state action" for these purposes. See Lynch v. United States, 189 F.2d 476 (5th Cir. 1951) ; Catlette v. United States, 132 F.2d 902 (4th Cir. 1943). Furthermore, it engages in affirmative action by illegitimately seating all the representatives from malapportioned districts after every election, and in appropriating the money to hold these illegal elections. 
Court could properly dispose of the issue before it solely by reference to the equal protection clause of the fourteenth amendment. No discussion of the provisions of article IV, section 4, would be needed for such a decision, since it was alleged that Tennessee's legislature had purposely failed to reapportion in order to preserve the disproportionate power of the minority residing in underpopulated districts. In so doing, it had intentionally disregarded the state's fundamental law, with a purposeful design of discriminating against the voters in overpopulated districts. ${ }^{40}$ Allegations of such action, in and of themselves, were sufficient to raise an equal protection claim.

\section{III}

WHAT NEXT FOR THE GUARANTEE AFTER Baker v. Carr?

In future apportionment cases the guarantee clause will unavoidably emerge as a major facet of the questions presented. The predicate of Baker was an admitted illegitimacy under state law created in a manner sufficient to raise fourteenth amendment claims. As bad as this kind of "malapportionment" is deemed by the "underrepresented" urbanite, his real dissatisfaction in many states ultimately hes elsewhere. It is in the schemes legitimated by the constitutions of many states that an unconscionably small minority finds its power to rule. A decision on the merits in favor of the plaintiffs in Baker v. Carr will almost certainly induce suits challenging the de jure scheme of representation in these states.

For example, Vermont's constitution entitles each town in the state to one representative in the state House of Representatives. Thus, one town with a population of 38 casts the sane vote in the state House as another with a population of 33,155 . As a result, 11.6 per cent of Vermont's electorate is entitled to a majority of the House's seats. ${ }^{50} \mathrm{~A}$ similar situation prevails in Connecticut, where 12 per cent of the electorate control the state House of Representatives and one House member represents 191 people, while another acts for 81,000 . This is fully sanctioned by the scheme of town representation provided for in Connecticut's constitution. ${ }^{51}$

40 See 82 Sup. Ct. at 725, where Justice Douglas notes that plaintiffs claimed an invidious discrimination in Baker, and states that the allegations supporting their contention were sufficient to entitle them to prove it in trial court. A purposeful or invidious discrimimation is, of course, inferrable from a settled course of conduct. Snowden v. Hughes, 321 U.S. 1, 8-11 (1944). Sce 82 Sup. Ct. at 696 n.10 for the history of the Tenuessee legislature's consistent failure to reapportion simce 1901. See also the table following Justice Clark's opinion, which demonstrates the extent of the inequity suffered because of the legislature's intentional failure to reapportion as required by the state's constitution. Id. at 734 .

${ }^{50}$ Lewis, Decision on Reapportionment Points Up Urban-Rural Struggle, N.Y. Times, April 1, 1962, § 4, p. 3, col. 2; Knowles, Study Details Rural Domination of Most Legislatures in Nation, N.Y. Times, March 28, 1962, p. 22, col. 2.

51 Ibid. 
After Baker, it is inevitable that attempts will be made to challenge the constitutionality of these kinds of state legitimated representational schemes. The assumption of such suits will be that the issues raised are so similar to Baker that they must also be justiciable. But cases of this class will present a different problem. For unlike $B a k e r$, they attempt to use the fourteenth amendment to question the validity of a state's de jure scheme of representation.

Regardless of the technical allegations of equal protection, no determination of this issue can be made without the Court's construing, and in effect enforcing, the guarantee of republican government. As Justice Frankfurter notes, although perhaps erroneously in the situation presented in Baker,

[S]ince "equal protection of the laws" can only mean an equality of persons standing in the same relation to whatever governmental action is challenged, the determination whether treatment is equal presupposes a determination concerning the nature of the relationship. This, with respect to apportionment, means an inquiry into the theoretical base of representation in an acceptably republican state. For a court could not determine the equalprotection issue without in fact first determining the Republican-Form issue, simply because what is reasonable for equal protection purposes will depend upon what frame of government, basically, is allowed. ${ }^{62}$

As a result, if the Court disposes on the merits of any future case questioning the validity of a state's de jure apportionment scheme, it will of necessity have to construe "republican form of government"; and by granting any relief on the equal protection claim, it will be enforcing the guarantee.

The Court could refrain from passing on the merits of the unspoken guarantee claims in such suits by deeming the issue presented in such cases nonjusticiable. The grounds for such a holding could be in conformity with some of the Court's previous assertions that the guarantee is totally unenforceable by the judiciary; and certainly Baker does not require a contrary result. However, several things indicate that this course of action will not be followed.

In the first place, Justice Clark necessarily intimated in Baker that the Court would examine the validity of a state's representational scheme under the fourteenth amendment, even though some determinations under the guarantee would be involved. In his view, that case required an assessinent of the "rationality" of Tennessee's de facto representational scheme itself. He concluded on the merits that it was a "crazy quilt without rational basis," and was therefore invalid. ${ }^{53}$ As Justice Franlffurter pointed out, any such determination must have entailed both a construction and sub silentio enforcement of the guarantee. 
Since Justice Douglas also admitted that the guarantee is not completely unenforceable by the courts, it was probable on the authority of Baker alone that at least these two Justices would entertain on the merits claims assailing the vahidity of a state's de jure representational scheme. Apparently neither of them would be dissuaded because a guarantee determination was implicit in the disposition of any such case. Add to this the unhappy insistence of Justice Frankfurter that the Court in Baker was actually passing on a guarantee claim, as well as some of the ambiguous language in Justice Brennan's opinion, and the likelihood of the Court's abstention in this future class of guarantee cases became extremely doubtful.

Only four weeks after Baker v. Carr, the Court rendered a decision that seems to leave little doubt about the course of action it will pursue. Scholle v. Hare, ${ }^{54}$ a suit assailing the validity of Michigan's de jure senatorial apportionment scheme, was remanded to the highest court of that state for reconsideration in light of Baker. The Supreme Court's action was seemingly motivated by the assumption that the Michigan courts had disposed of the case on the erroneous view that the fourteenth amendment rights alleged there were not enforceable by the courts.

As a result, the Scholle case intimates that the following question is justiciable: Does the equal protection clause prohibit a state from establishing by its constitution senate electoral districts by geographic areas, drawn generally along county lines which result in substantial inequality of voter representation favoring thinly populated areas as opposed to populous ones? ${ }^{55}$ As noted previously, the answer to this question involves an assessment of the permissible schemes of representation in a republican state; for the extent to which there is any right to "equality of representation" depends upon the state's freedom to institute legislative schemes departing from that theory. And the amount of such freedom rests upon the latitude accorded the states by the guarantee of republican government.

So in cases like Scholle v. Hare, any determination on the merits must involve an assessment of the permissible limits allowed representational schemes by the guarantee. If the assailed scheme is republican, then it cannot deprive plaintiff of equal protection; but if it is not republican, then it does. Under the guise of equal protection, the Court in Scholle has therefore seemingly made a sub silentio decision to enforce the guarantee in this class of cases. But to sensibly accept such jurisdiction, it must be able to evolve satisfactory criteria to test the republican nature of state representational schemes-a task it did not have to face in Baker, or cases like it.

It is submitted that this is as much within the Court's capabilities as its

5430 U.S.L. WEEK 3332 (U.S. April 23, 1962) (per curiam).

55 See ibid. (Harlan, J., dissenting). 
proved capacity to evolve standards for application of the due process and equal protection clauses of the fourteenth amendment. However, any attempt to create standards by which to gauge the validity of a state's de jure apportionment scheme under the cloak of equal protection, without noting the real involvement of the guarantee, can only cause mischief in the future. Hiding the real issue in this potential class of suits by such a fiction will render their proper analysis and solution more difficult. ${ }^{56}$

\section{IV}

\section{WHAT MINIMUM STANDARDS MIGHT THE GUARANTEE MANDATE FOR}

\section{STATE APPORTIONMENT SCHEMES?}

Several schemes that might be used by the Court to test the republicanism of a state's system of representation can be ventured. They are suggested solely to demonstrate that the guarantee can provide sufficient standards to justify the Court's intrusion in such cases, but are not offered as definitive solutions to the problem. An mitial attempt might be made to subject the state's de jure scheme of representation, on its face, to the test of historical development and contemporary expectations. Such an effort, which is fully warranted by the mandates of the guarantee ${ }^{57}$ must obviously conclude that any governmental scheme calculated to weigh the people's influence according to their numbers is republican. So it has always been in this country, and certainly it accords with popular expectations.

Equally obvious, though perhaps unhappily conceded by some, is the conclusion that a scheme giving political or geographic units equal participation in one house of a state's legislature is on its face republican. Despite the fact that the units may have populations of differing sizes, "no one... contends that mathematical equality among voters is required" in all cases. ${ }^{58}$ And such schemes of geographic representation also follow a tradition coterminous with our "Republic" and not so at odds with current expectations as to be rendered unrepublican. As a newspaper analyst of some note in this field recently remarked,

56 On April 28, 1962, a three-judge federal district court held that Georgia's newly modified county-unit electoral system violated the equal protection clause of the fourteenth amendment. N.Y.Times, April 29, 1962, p. 1, col. 6, p. 55, col. 1. There apparently was no discussion of the inexorable involvement of art. IV, $\S 4$, in that determination. This is regretable, for by that omission the opinion fails to indicate its real basis. The court could only conclude that the unit system was unconstitutional if the amount of favoritism it accorded rural over urban areas in choosing certain state officers was unrepublican. However, the court failed to articulate the unavoidable determination of how much power unrelated to population can be given to regionaI units in a republican state. Thus, the decision will not help future litigants to understand the crucial issue involved in the Georgia suit and in the projected class of suits discussed in the text.

57 See Bonfield, supra note 4, at 558-60.

6882 Sup. Ct. at 732 (Clark, J., concurring). 
In view of the long history in this country of weighing geographical inter ests in representative systems, it seems most doubtful that the Supreme Court will require districts of approximately equal population. Many legal observers believe, for example, that a deliberate choice to make one house of a legislature represent people, and the other counties, . . . might pass muster. ${ }^{59}$

And almost surely it will, at least on its face.

So at first glance, the state constitutional preference of Connecticut and Vermont to ground one of their houses on the equal representation of towns must pass muster. But what of New Hampshire's scheme? Its constitution directs the legislature to divide the state into twenty-four districts, each to have one senator. In making this division, the legislature "shall govern themselves by the proportion of direct taxes paid by the said district." Under such a plan each senator represents about the same dollar amount of taxes paid, but varying numbers of people. It may be suggested that this scheme violates the strictures imposed by the guarantee. While any system of geographic or political-unit representation would seem unobjectionable on its face, the scheme to represent wealth employed in New Hampshire would seem most vulnerable. It is so out of tune with current mores and expectations, and even with the historical development of this nation, that it can hardly fail to be regarded as unrepublican. For the scheme is patently directed at affording individuals a voice in government proportionate to their wealth or the wealth of those who surround them. There is little precedent outside of this case for such a concept, notwithstanding the poll tax and other earlier property qualifications on the franchise. These were not calculated to multiply the voice of an mdividual in direct proportion to his or his neighbor's wealth.

The final poimt that may be noted about the prima facie requisites of a republican legislative scheme is similarly derivable from the historical development of our Republic, as well as the current mores and expectations of the American people. To pass muster, the representation of at least one house of a state's bicameral legislature must in some manner be geared to accord weight to numbers, so that a substantial dedication to the principle of "one man, one vote" is obvious. Notwithstanding the de facto but illegitimate apportionment that has often subinerged this principle, this has most often been mandated by the state constitutions. And certainly current expectations of the American people about the nature of their republican governments would demand that at least one house be grounded on such

${ }^{59}$ Lewis, Decision on Reapportionment Points Up Urban-Rural Struggle, N.Y.Times, April 1, 1962, \& 4, p. 3, col. 8 .

${ }^{80}$ N.H. Const. pt. 2 art. 26. See BAKER, State Constrututions 12 (1960), noting that because of a failure to reapportion on this basis simce 1915, the present distribution approximates what an apportionment based on the 1950 population would have yielded. 
a theory. ${ }^{61}$ As the Supreme Court has noted, in trying to define some of the requisites of republican government,

the people are the source of all political power, but as the exercise of governmental powers immediately by the people themselves is impractical, they must be exercised by the representatives of the people.... [T] he basis of such representation is suffrage... [and] through its regulated exercise each man's power tells in ... the enactment of laws ... .22

Assuming that a state's representational scheme is republican on its face, it is unlikely that the Court's investigation will cease. The guarantee embodied im article IV, section 4, was obviously not meant to be one solely of form, or sham, but rather of substance. ${ }^{03}$ In any case raising the validity of a state's de jure scheme of representation, the Court will therefore have to examine its republicanism in practice. Otherwise, a state could maintain a system of representation that merely appears republican, without actually being so.

Consider several statistics demonstrating the percentage of electors invested with control of the following states' geographically grounded houses: Nevada, 8 per cent; California, 10.7 per cent; Vermont, 11.6 per cent; Connecticut, 12 per cent; Florida, 12.3 per cent; and Arizona, 12.8 per cent. ${ }^{64}$ Of course, these houses must concur in all state legislative action. Can a scheme of representation whose apphication permits such a small percentage of the electorate to control the legislative process be deemed republican? It is extremely doubtful, for as Madison noted in The Federalist, a republic is

A government which derives all its powers directly or indirectly from the great body of the people. ... It is essential to such a government, that it be derived from the great body of the society, not from an inconsiderable proportion or a favored class of it..$^{05}$

But low small must the proportion of electors invested with control of a state's legislative process be before the otherwise valid scheme of regional representation that sanctions it becomes unrepublican? It must be obvious that the states just mentioned are not governed by "the great body of

6134 of the 50 states weigh representation in one or more of their houses solely according to population; 5 more states apportion at least one house on the basis of population, but give a seemingly neghigible advantage to less populous areas by allowing a seat to a county that has a stipulated portion of a ratio. See BaKER, op. cit. supra note 60, at 5-8,63-70. This leaves 11 states that might fall short of this requirement of republican government.

62 In re Duncan, 139 U.S. 449, 461 (1891) (paraphrasing Daniel Webster). (Emphasis added.)

B3 See Bonfield, supra note 4, at 530.

04 Knowles, Study Details Rural Dontination of Most Legislatures in Nation, N.Y.Times, March 28, 1962, p.22, col. 1 .

65 The Federalist No. 39, at 246-47 (Ford ed. 1898) (Madison). (Emphasis added.) 
people," in Madison's sense. It is probably equally clear that the current expectations of the American people would cause them to recoil from any attempt to equate legislative schemes that sanction the extreme results just noted with republican government.

It may well be poimted out, however, that only 16.5 per cent of the American voters are entitled to elect a majority of the seats in the United States Senate. ${ }^{66}$ And few would deny that that body is a republican institution. But can this justify a state system of geographic representation that does the same? It cannot, and there are sufficient differences between the two situations to demand a state's adherence to a higher standard of popular control in any scheme it adopts to weigh regional interests in its legislative process.

The Senate of the United States was geared to insure equal representation to equal and independent sovereigns within a government created by the cession of some of the sovereignty of each. It is not unreasonable to argue, therefore, that in some part of the legislative process this pre-existing sovereign equality should be respected, regardless of comparative population. This feeling was so prevalent at the birth of our nation that a provision was inserted in the Constitution requiring a state's consent before it could be divested of that equality. ${ }^{67}$

But the intrastate geographic or political units, which may be quite rationally represented in one house of a state's government to a degree larger than their population alone warrants, were never sovereigns among equals. They are mere creatures of the state and are represented in the legislature solely as a rational way to give adequate weight and consideration to varying regional viewpoints. In short, such units enjoy equal representation regardless of their comparative population because of a legitimate state policy choice, and not because of any innate rights of equal sovereignty as are represented in the national Senate.

Furthermore, when one adds to the unique justification for the Senate the greater physical expanse and cultural diversity of the United States in comparison with any one state, that body becomes an even more dubious model for state representational schemes.

These factors adequately justify giving far more weight in the Senate to regional interests unrelated to population, than any state would be warranted in doing in one of its legislative bodies. And, of course, it is inconceivable that any legislative process controlled by less than 16.5 per cent of the electorate could be deemed responsive to "the great body of the people." It would seem reasonable, therefore, to denominate any system of

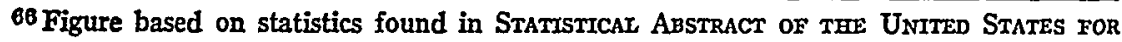
1961 , at 360 .

67 U.S. Const. art. V. 
state representation "unrepublican" if it accords greater weight in either louse to regional interests than is done in the United States Senate. ${ }^{68}$

The failure of the schemes of geographic representation employed by the states to present the same justification as that in the United States Senate may well warrant their being held to a liigher standard of popular control under the guarantee. One way of doing so, while respecting the individuality of state systems of representation, might be as follows. If a state's scheme to weigh regional interests in its legislative process endows a significantly smaller proportion of its electorate with control of either house than was required when it was admitted to the Union, it should be invalidated as "unrepublican."

The virtue of this yardstick is that Congress must have assumed when it admitted that state to the Union that its representational scheme was republican. Congress having by implication spoken on the subject, the Supreme Court might feel morally bound to maintain that degree of popular government present in the state at the time of its admission. ${ }^{69}$ It would liardly seem unfair, or disrespectful of the imdividuality of state representational schemes, to bar any state from permitting a majority's control over the legislative process to regress. Each state would be entitled to the system it finds best in this regard, so long as it does not retreat from the origimal standard of popular control that it set for itself when it entered the Union.

It can be argued, lowever, that this fails to provide a satisfactory standard. The practical application of the state's sclieme to weigh regional interests may have originally accorded control of its geographically constituted house to a far larger percentage of its electors than required by the guarantee. While this is true, policy would seem to indicate an adherence to current expectations. Chief among these, certainly, is the idea that the control of the government by the mass of the people through the electoral process should not be permitted to decrease. Though "malapportionment" has thwarted this principle during the last twenty or more years, ${ }^{70}$ it has been solely a product of the disproportionate power wielded by a minority entrenched by the present system. It therefore in no way reflects upon the current expectations of the American people that the majority's control over

B8 In the Georgia county-unit case discussed supra note 56, the court found the scheme invalid because of its failure "to accord the units representing a majority of the population a reasonable proportion of the whole" number of votes counted in primary elections. The opponents of the county-unit systent contended that its diffusion of governing power accorded ouly 15.4 per cent of the state's electorate the power to nominate, and in effect elect, nuany important state officers. See N.Y.Times, April 29, 1962, p. 1, col.6, p.55, col.1.

09 But this should not be taken to mean that Congress' assessment of the republican nature of a state's government is conclusively binding on the Court. See Bonfield, supra note 4 , at $562-63$.

70 Lewis, Decision on Reapportionnent Points Up Urban-Rural Struggle, N.Y.Times, April 1, 1962, §4, p. 3, col. 2. 
the electoral process must not be allowed to wane. It appears, therefore, that contemporary notions of republican government will also justify the imposition of this suggested limitation on the operation of state schemes for regional representation.

In any case before it the Court would seem justified in testing the "republican" nature of a state's de jure scheme of geographic representation, by comparing it with the ligher of the two standards suggested. The proportion of a state's electors now endowed with control of its geographically grounded house must therefore be compared with the proportion at the time of its admission to the Union and the analogous proportion found in the Uirited States Senate. If the scheme vests such control in a significantly smaller percentage of electors than the larger of these two, it may be deemed unrepublican.

Two things should be noted about the suggested standards. First, because of the urbanization that has occurred in most states since their admission to the Union, the percentage of the electorate represented by a majority of a state's geographically constituted louse lias appreciably declined. In a large number of cases, this decline lias been sufficiently significant to justify voiding the state's otherwise valid sclieme to weight regional interests in its legislative process. Indeed, urbanization has distorted geographic schemes of representation to such a point that in some states a smaller percentage of voters may be represented by a controlling interest in that process than in any state at the time of its admission. Secondly, even using the percentage of the electorate necessary to control the United States Senate will have a significant impact: If it is used as a minimum gatige of the reasonableness of a state's scheme to weight regional interests in its legislative process, many legislative bodies will be found unrepublican. ${ }^{\mathbf{7 1}}$

\section{CONCLUSION}

The standards suggested liere by which the "republican" nature of a state's de jure representational scheme can be assessed are highly tentative. No doubt more mature consideration will evolve newer and more satisfactory criteria to accomplisli this result. Pursuant to its duty under the guarantee, Congress miglit even pass a statute containing such standards. The function of this article, however, has not been to offer any definitive answers on that score.

Rather, this effort has souglit to nake several simple points. First, it should be the particular issue raised under the guarantee, and not the mere invocation of that provision, that renders a case nonjusticiable. Second, Baker v. Carr did not itself involve any judicial determination under the guarantee. Third, regardless of the Court's intention, the instant case is

71 See states enumerated in text accompanying note 64 stupra. 
bound to produce a rash of suits assailing the validity of several states' de jure schemes of representation; and the disposal of any such suits on the merits will inevitably involve determinations under the guarantee.

Finally, if the Court can devise a remedy in Baker v. Carr, it can do so in this class of future suits. Moreover, the issue involved in this kind of suit will contain no more of the elements of nonjusticiability than the ultimate question facing the Court in Baker. Specifically, the Court can create satisfactory standards under the guarantee to properly resolve cases assailing the validity of a state's de jure scheme of representation. But it should avoid attempting to do so under the guise of equal protection, since such action will only further obscure the real issue in these cases, and thereby render its proper solution more difficult.

Whether the Supreme Court should grant relief in every suit assailing the validity of a state's de jure scheme of representation presents other considerations. It would seem fair to argue that it should do so, at least in every case in which the imtiative or some other device is unavailable to enable the majority to take matters into their own hands. It is hard to say, for example, that a majority of Vermont's citizens really want their house apportionment by towns to remain as it has been since 1793. Since legislative action is a prerequisite to any change in the present scheme, which permits 11.6 per cent of the population to control the lower house, there is virtually no chance for the underrepresented majority to cure its dissatisfaction with the system.

Michigan, however, presents a contrary situation. There, the majority can resort to the intiative to cure any dissatisfaction with the state's present scheme of representation. Indeed, "the challenged electoral apportionment [in Scholle v. Hare] reflects the desires of Michigan's citizenry, as expressed in a 1952 popular referendum . . .."72 And presumably, any change in the majority's attitude since could be implemented by the initiative.

In any situation like Michigan where the nuajority has a practical political remedy by which it can change the legal basis of legislative apportionment to better reflect its views, the federal courts should abstain from providing relief. ${ }^{73}$ In these cases there is no overriding necessity warranting the equitable intervention of the federal judiciary into areas embroiled $\mathrm{m}$ local politics. And a due respect for the nature of our federal system and its attendant virtues would dictate such a finding of great necessity as a prerequisite to the involvement of the national courts in such matters.

72 Scholle v. Hare, 30 U.S.L. WEEK 3332, 3333 (U.S. April 23, 1962) (Harlan, J., dissenting).

73 See Justice Clark's observation that plaintiffs had no practical political remedy, such as the initiative, by which they could cure the legislature's malapportionment. 82 Sup. Ct. at 732-33. 